\section{Either Or}

Oshrat C. Silberbusch

Krisis 41 (2): 104-105.

DOI

10.21827/krisis. 41.2 .38253

\section{Licence}

This work is licensed under a Creative Commons Attribution 4.0 License International License (CC BY 4.0). (C) 2021 The author(s). 


\section{Either Or}

Oshrat C. Silberbusch

The a priori reduction to the friend-foe relationship is one of the Ur-phenomena of the new anthropology. Freedom would be not to choose between black and white but to step out of such prescribed choice. $(\$ 85)$

Either Or, which holds such sway these days, is about much more than political polarization. It is about a strangely contracted imagination, about thought broken off, freedom crushed by prescribed choices. The prescription is all the more inescapable as, by all accounts, there is no prescriber. In their stead, there is paucity: the reduction of an infinitely complex reality to the black and white of the Either Or, the squeezing of the messy, unruly phenomena into a neat binary. Red or Blue, Pro-Life or Pro-Choice, Free Markets or Servitude, Live Free or Die, Pro-Vaccine or Antivaxx. Binary thinking is identity thinking on steroids. Everything is either friend or foe, A or not-A. There is no need for reflection, only sorting. The answer is already given. Just check the box.

Either Or forces thought into a corner, a corner in which reflection is stifled or worse: a threat, a dangerous concession to the other side. Just like in the One Drop Rule - the paroxysm of America's primal binary - the most infinitesimal trace of not-A erases A, turns it into its opposite. There is no in-between, no nuance, no new coming out of the old, no infinity of possibilities, only a jealously guarded Either Or for which intransigence is strength and humility a weakness. Lost is the possibility of true reflection, the richness of an argument not decided in advance. Lost is the fragile freedom in which thought blossoms, the quest for a truth that can only be found because it can be lost. For Adorno, the ability to think, to reflect, hinged on the ability to see in the small difference a Differenz ums Ganze - a difference that changes everything. In the world of Either Or, there are no small differences, only the Big One, and there is no change either, certainly no change of mind - only fixity, ever-sameness, and the unshakeable conviction to be on the right side.

Either Or is the language of power. It tends to be most forceful where power needs to be consolidated or feels under threat. In America, British settlers, at the forefront of their white supremacist times, created a black-white binary so rigid that it would outdo all its colonialist peers in exploitative power and longevity. Spanish settlers, on the other hand, relied on a complex nomenclature of intermixtures (negros, mestizas, mulatas, moriscos, castizas, albinos, barcinas, cambujos, zambaigas, and many more) whose multiplicity undermined the very hierarchy it aimed to construct. Power relies on the constriction of the possible, on the withering of social and political imagination. Complexity, multiplicity, ambiguity, and nuance feed the imagination. They are the beginning of freedom, just as Either Or is its end. Those who trumpet the prescribed choices know that all too well. They do not want you to be free; they do not even want you to choose. They want you to believe that there is no alternative.

Either Or thrives on fear. "Either" it ominously rumbles, "or else...". War, imagined or real, is its terrain of choice. In the United States, the protracted Cold War, with McCarthyism as its brief but revealing ideological paroxysm, has led to a withering 
of the collective political imagination whose legacy continues. But America, as Adorno knew all too well, is not an exception - it is the exaggeration that is the medium of truth, always one step ahead. The thought-structure that the One Drop Rule and McCarthyism relied on and perpetuated, the merciless A or not-A, is alive and well and can be found everywhere. As the prescribed choices become ever more entrenched, the capacity to step out of them wilts away. For the sake of that very freedom whose name is so often fraudulently invoked by the Either Or, we need to relearn, urgently, not to choose between black and white.

\section{Biography}

Oshrat C. Silberbusch holds a PhD in Philosophy from Tel Aviv University and an MA in German Studies from the Université de la Sorbonne Nouvelle, Paris. She is the author of Adorno's Philosophy of the Nonidentical. Thinking as Resistance (Palgrave Macmillan, 2018) and has written articles on Theodor W. Adorno, Jean Améry, W. E. B. Du Bois, George Orwell, Günther Anders, post-Shoah thought and German-Jewish history. She lives in Brooklyn with her husband and three children. 